\title{
DETERMINATION OF EFFECTIVENESS ABSORPTION OF THE RICE HUSK AND HAZELNUT SHELL TO PURIFICATION USED COOKING OIL
}

\author{
Loth Botahala $^{1 *}$, Yanti Malailak ${ }^{2}$, Herlin Silvia Maure ${ }^{1.2}$, dan Hagar Karlani ${ }^{1.3}$ \\ ${ }^{1}$ Chemistry Study Program, Faculty of Mathematics and Natural Sciences, \\ University of Tribuana Kalabahi - Alor \\ ${ }^{2}$ Christian High School 1 Kalabahi, Alor - NTT \\ *Corresponding author: botahala@gmail.com
}

\begin{abstract}
Abstrak. Uji efektivitas daya serap arang aktif sekam padi dan cangkang kemiri terhadap penjernihan minyak goreng bekas telah dilakukan. Tujuannya untuk menentukan kemampuan daya serap dari arang aktif sekam padi dan cangkang kemiri terhadap penjernihan minyak goreng bekas. Arang cangkang kemiri dan sekam padi dibuat dengan suhu $400{ }^{\circ} \mathrm{C}$ selama 90 menit dan diaktivasi secara fisika dengan suhu $350^{\circ} \mathrm{C}$ selama $1 \mathrm{jam}$. Setelah itu, arang aktif dari sekam padi dan cangkang kemiri diaplikasikan pada penjernihan minyak goreng bekas. Kadar air dan kadar abu kedua arang aktif yang dihasilkan sebesar masing-masing 3,398 \% dan 6,667 \% untuk arang aktif cangkang kemiri serta 3,355 \% dan 8,667 \% untuk arang aktif sekam padi. Setelah diaplikasikan pada penjernihan minyak goreng bekas, daya serap arang aktif cangkang kemiri dan sekam padi terhadap bilangan peroksida sebesar masing-masing $66 \%$ dan $59 \%$ dari total 2,73 meq dalam sampel serta asam lemak bebas sebesar masing-masing 60,6\% dan 45,4\% dari total $0,33 \%$ dalam sampel. Dengan demikian, dapat disimpulkan bahwa penggunaan arang aktif cangkang kemiri lebih efektif bila dibandingkan dengan arang aktif sekam padi pada penjernihan minyak goreng bekas.
\end{abstract}

Kata kunci : absorpsi, karbon aktif, cangkang kemiri, sekam padi

\begin{abstract}
The effectiveness of the absorption of activated rice husk and hazelnut shells on the purification of used cooking oil has been carried out. The aim is to determine the absorption capacity of the active charcoal of rice husk and hazelnut shells to purify used cooking oil. Candlenut shell charcoal and rice husk are prepared with a temperature of $400{ }^{\circ} \mathrm{C}$ for 90 minutes and activated in physics with $350^{\circ} \mathrm{C}$ for 1 hour. After that, activated charcoal from rice husk and candlenut shells was applied to purifying used cooking oil. Water content and ash content of both activated charcoal were $3.398 \%$ and $6.667 \%$ for candlenut shell charcoal and $3.355 \%$ and 8.667 $\%$ for activated rice husk charcoal. After being applied to the purification of used cooking oil, the absorption of candlenut shells and rice husk on peroxide numbers was $66 \%$ and $59 \%$ respectively from the total 2.73 meq in samples and free fatty acids of $60.6 \%$ and $45.4 \%$ of the total $0.33 \%$ in the sample. Thus, it can be concluded that the use of candlenut shell charcoal is more effective when compared with activated rice husk charcoal in purifying used cooking oil.
\end{abstract}

Keywords: absorption, activated carbon, hazelnut shell, rice husk. 


\section{INTRODUCTION}

Charcoal is a porous solid material that is produced through carbonization from carbon-containing materials (Mody Plate, 2011). According to Sudrajat $P$ and Tjipto Utomo (2005), activated charcoal is activated the charcoal by immersion in the chemicals or by flowing hot steam into the material so that the material pores become more open. Because of the more active charcoal surface area, the higher absorption of the material against gas or liquid. Meanwhile, according to $\mathrm{P}$. Hariprasad et al., (2016) Activated carbon is a form of carbon that has been processed to make it very porous so that it has a very wide surface area.

Basically activated carbon is characterized by physical and chemical properties. The physical properties of activated carbon, such as ash content and moisture content can affect the use of activated carbon. SNI-06-3730-1995 describes the requirement for $15 \%$ maximum activated carbon water content and $10 \%$ maximum ash content. While the specific surface area of activated carbon is classified as a chemical property. Furthermore, the porous structure of activated carbon can be characterized by various techniques such as gas adsorption $\left(\mathrm{N}_{2}, \mathrm{Ar}, \mathrm{Kr}, \mathrm{CO}_{2}\right)$ or steam (benzene, water). To determine the ash content, the temperature must be below $600^{\circ} \mathrm{C}$ to minimize evaporation of inorganic elements, and also allow ash to be in suitable conditions for further examination (Al-Qodah Z. et al., 2009).

The amount and size of the material to be absorbed by activated carbon depends on the pore size and surface area of the activated carbon. According to Aznar S.J. (2011) and AlQodah Z. et.al. (2009), Pores are a type of cavity or empty space that is connected to the surface of a solid and allows the release of liquid into or from the material. Basically, pores are classified into three groups according to the International Union of Pure and Applied Chemistry (IUPAC), namely Micropore (D 0.04-2 nm), Mesopores (D 2-50 nm), and Macropore (D> $50 \mathrm{~nm}$ ) (Ansar, 2012 in Santi, 2012 and Aznar SJ, 2011). Micropore is the most important cavity because the smaller size shows a very high surface area, so it can produce a higher absorption capacity. (Aznar S.J., 2011 and Al-Qodah Z. et al., 2009). Mesopores has a dual function because with a diameter of $2-5 \mathrm{~nm}$ it can absorb / store molecules that are sized between macropore and micropore (Aznar S.J., 2011). In carbon, mesoporous can be formed by micropore enlargement (Al-Qodah Z. et.al., 2009). Macropores are large pores that function to facilitate the absorption of micropores and mesopores that are deeper than micropores on activated carbon. Even so, macropores can also hold large molecules, which result from the decomposition of organic matter.

Properties and quality assay of the activated charcoal produced, both from the process of activating hazelnut charcoal and from the activation process of rice husk charcoal has been carried out. For example, activation of pecan shell charcoal with heat activator and steam $\mathrm{H}_{2} \mathrm{O}, \mathrm{CaCl}_{2}, \mathrm{KOH}$, and activation of rice husk charcoal with an activator of $\mathrm{ZnCl}_{2}$ solution (Lempang et al., 2012; 
Darmawan et al., 2009; Zakir et al., 2013). According to Nur R. (2012) and Darmawan et al. (2009), carbon activation aims to enlarge the surface area of carbon by opening closed pores so that it can increase absorption.

The application of hazelnut shells and rice husks has been carried out. For example hazelnut shells as adsorbents to toluene gas (Wuntu et al., 2013), as raw material for briquettes (Patabang Daud, 2009), for purifying used cooking oil (Botahala L. et al., 2016), and others. While the application of rice husk as an adsorbent to methylene blue dyes (Taba et al., 2013), as silica in red brick (Indra et al., 2013), as an additive to cement production (Botahala L. et al., 2013), and others.

Cooking oil is included in one of the food items that are needed by the society to fulfill daily needs with oil quality based on SNI-01-3741-1995 concerning cooking oil. The need for cooking oil is increasing with the increasing population in Indonesia, so the used cooking oil produced is increasing as well (Botahala L. et al., 2016). The use of cooking oil both for industry and households, produces used oil which still contains high enough fatty acids because it is used repeatedly (Wijayanti Kartika, 2015; Evika, 2011). Decomposition of oil component can be observed visually, namely the appearance of odor, brownish color and rancid taste caused by oil oxidation. The greater the level of free fatty acids, the lower the quality of the cooking oil (Nasir et al., 2014). Continuous use of used cooking oil harmful for human health, cause cancer, deposition of fat in blood vessels (artherosclerosis) and decrease fat digestibility, and other consequences is to reduce the intelligence of the next generation (Rukmini Ambar, 2007; Evika, 2011).

Thus, in this study a comparison of water content and ash content will be carried out, as well as absorption between the active charcoal of rice husk and hazelnut shell charcoal which is applied to the purification of used cooking oil.

\section{MATERIAL AND METHOD Materials and Tools}

This research was conducted in January - March 2017 at the Chemistry Laboratory, Faculty of Teacher Training and Education, University of Nusa Cendana Kupang. The materials used in this study were rice husk and hazelnut shells and used cooking oil taken from Alor Regency, $16 \%$ Sodium Hydroxide $(\mathrm{NaOH})$, Acetic Acid $\left(\mathrm{C}_{2} \mathrm{H}_{4} \mathrm{O}_{2}\right)$, chloroform $\left(\mathrm{CHCl}_{3}\right), \quad$ saturated Potassium Iodide (KI) solution, Sodium Thiosulfate $\left(\mathrm{Na}_{2} \mathrm{~S}_{2} \mathrm{O}_{3}\right), 1 \%$ starch solution, indicator $\mathrm{pp}$, aquades and ethanol. The tools used in this study consisted of Muffle Furnace, grinder, 100 mesh sieve, Stirrer and Magnetic Stirrer, Stirring Rod, Universal Indicator Paper, Glass Cup, Erlenmeyer, Measuring Cup, Drop Pipette, Analytical Scales, Porcelain Saucer, Separate Funnel, Oven Dryers, cans and Pumpkin Measure. 


\section{Procedure}

\section{Making and testing hazelnut shells and rice husks}

Rice husk and hazelnut shells, which are clean and dry, are heated in a furnace (Muffle Furnace) at $400{ }^{\circ} \mathrm{C}$ for 90 minutes until carbon is formed. After that it is cooled for 24 hours in the Muffle Furnace. then the charcoal is released and milled using pengilingan to form a powder. Charcoal is activated physically by putting it in a can and then given a small hole in the can lid after that the charcoal is heated at $350^{\circ} \mathrm{C}$ for 1 hour then the activated charcoal is ready to use.

\subsection{Determination of Water Content}

Weighing activated charcoal weighing 1 gram each and putting it in a dried porcelain dish. After that it was heated in an oven at $100{ }^{\circ} \mathrm{C}$ for 3 hours, then the charcoal was cooled in a desiccator and weighed. Water content can be calculated by the equation according to Surest et al. (2008) as follows:

$$
\% \text { Water Content }=\frac{a-b}{a} \times 100
$$

Where:

$\mathrm{a}=$ cup weight + sample before heating (gram)

$\mathrm{b}=$ cup weight + sample after heating (gram)

\subsection{Determination of Ash Content}

Weighing activated charcoal weighing 1 gram each and putting it in a dried porcelain dish, after that it was heated in Muffle Furnace at $500{ }^{\circ} \mathrm{C}$ for 3 hours, then the charcoal was cooled in a desiccator and weighed. Ash content can be calculated with the following equation:

$$
\% \text { Ash Content }=\frac{c-a}{b-a} \times 100
$$

Where:

$\mathrm{a}=$ weight of empty cup (gram)

$\mathrm{b}=$ cup weight + sample before heating (gram)

$\mathrm{c}=$ cup weight + sample after heating (gram)

\subsection{Analisys of used cooking oil}

This procedure is carried out by analyzing the quality of used cooking oil, as done by Padalowa N. (2015) with several modifications according to the research objectives. The tests are carried out in two stages, namely the stages of purifying used cooking oil and the testing phase.

The purification stage is intended to clean used cooking oil from other spices and impurities. While the testing phase is intended to test the effectiveness of activated charcoal absorption using the titration method.

\subsection{Purification stages}

\subsubsection{Despicing process}

A total of $250 \mathrm{~mL}$ of used cooking oil is added to the water with the composition of oil: water (1: 1), put into a $500 \mathrm{~mL}$ glass cup. Then it is heated at a temperature of $1000 \mathrm{C}$ until the water in the glass cupper is half. The mixture is left in a separating funnel for 1 hour, then the water fraction at the bottom is separated so that oil is free of water, after which filtering is carried out with filter paper to separate the remaining impurities. 


\subsubsection{Neutralization process}

As much as $150 \mathrm{~mL}$ of cooking oil from the removal of seasonings are put in a $500 \mathrm{~mL}$ glass cup and heated while sterilized to $35^{\circ} \mathrm{C}$, then $6 \mathrm{~mL}$ of $16 \%$ $\mathrm{NaOH}$ solution, then cooled for 10 minutes and filtered with filter paper and then purification process.

\subsubsection{Purification process (Bleaching)}

The purification process is done by using sample variables as determined based on the matrix in Table 1.

Table 1. Research matrix for the purification process (Bleaching)

\begin{tabular}{lcl}
\hline No & $\begin{array}{c}\text { Sample } \\
\text { Code }\end{array}$ & \multicolumn{1}{c}{ Sample Name } \\
\hline 1 & S0 & Used cooking oil \\
\hline 2 & S1 & $\begin{array}{l}\text { Used cooking oil }+ \\
\text { activated charcoal } \\
\text { from hazelnut shell }\end{array}$ \\
\hline 3 & S2 & $\begin{array}{l}\text { Used cooking oil }+ \\
\text { activated charcoal } \\
\text { from rice husk }\end{array}$ \\
\hline
\end{tabular}

cooking oil neutralized at a temperature of $100^{\circ} \mathrm{C}$ in 60 minutes. Then the solution is filtered and analyzed for quality.

\subsection{Testing stages}

\subsubsection{Determination of Peroxide Numbers}

A total of $5 \mathrm{~mL}$ of cooking oil was put into erlenmeyer then added $30 \mathrm{~mL}$ of acetic acid - chloroform (3: 2), shaken until the ingredients were completely dissolved, then added $0.5 \mathrm{~mL}$ of saturated KI solution. Let stand for 1 minute while shaking after that $30 \mathrm{~mL}$ of distilled water was added. The mixture was titrated with $0.1 \mathrm{~N} \mathrm{Na} 2 \mathrm{~S} 2 \mathrm{O} 3$ until yellow, added $0.5 \mathrm{~mL}$ of $1 \%$ starch solution and titrated again until the blue color began to disappear. The peroxide number expressed in milliequivalents of peroxide is calculated from every 1000 grams of the sample.

Each of 10 grams of activated charcoal was mixed with $50 \mathrm{~mL}$ of used

ml Na${ }_{2} \mathrm{~S}_{2} \mathrm{O}_{3}=$ Titran volume $\mathrm{Na}_{2} \mathrm{~S}_{2} \mathrm{O}_{3}$

$$
\text { Peroxide Numbers }=\frac{\mathrm{ml} \mathrm{Na}_{2} \mathrm{~S}_{2} \mathrm{O}_{3} \times \mathrm{N} . \mathrm{Na}_{2} \mathrm{~S}_{2} \mathrm{O}_{3} \times 1000}{\text { sample }(\text { gram })}
$$

N. $\mathrm{Na}_{2} \mathrm{~S}_{2} \mathrm{O}_{3}=$ normality of solution $\mathrm{Na}_{2} \mathrm{~S}_{2} \mathrm{O}_{3}(=0,1)$

\subsubsection{Determination of Free fatty acids}

A total of $10 \mathrm{~mL}$ of cooking oil is put into a $250 \mathrm{~mL}$ erlenmeyer, then 25 $\mathrm{mL}$ ethanol is added and heated at $40^{\circ}$
$\mathrm{C}$, then 2 drops of pp indicator are added, titrated with $0.1 \mathrm{~N} \mathrm{NaOH}$ solution until the color pink and not lost for 30 seconds. Free fatty acid (\% FFA) is calculated by the formula below:

$$
\% F F A=\frac{\mathrm{mLNaOH} \times \mathrm{N} \mathrm{NaOH} \times \mathrm{BM} . \text { palmitat acid }}{\text { sample weight } \times 1000} \times 100
$$

$$
\begin{array}{ll}
\% F F A & : \text { Free fatty acid content } \\
\mathrm{mL} \mathrm{NaOH} & : \text { Volume of } \mathrm{NaOH} \text { titrant } \\
\mathrm{N} \mathrm{NaOH} & : \text { Normality of } \mathrm{NaOH} \text { Solution }(=0.1) \\
\mathrm{BM} & : \text { Molecular palmitat acid weight }(256.42 \mathrm{~g} / \mathrm{mol})
\end{array}
$$




\subsubsection{Determination of water content}

Erlenmeyer is heated in an oven at $105^{\circ} \mathrm{C}$ for 1 hour. Then cool for 15-20 minutes at room temperature. Then erlenmeyer is weighed, the results are recorded and repeated 3 times until the results are constant. A total of $2 \mathrm{~mL}$ of sample was put into erlenmeyer, then heated in an oven at $105^{\circ} \mathrm{C}$ for 2 hours. After that it is cooled and weighed erlenmeyer containing the sample. Weighing is done 3 times until a constant weight is obtained. Water content is calculated based on the equation:

$$
\% \text { Water Content }=\frac{a-b}{a} \times 100
$$

Where:

$\mathrm{a}=$ cup weight + sample before heating (gram)

$\mathrm{b}=$ cup weight + sample after heating (gram)

\section{RESULTS AND DISCUSSION}

\section{Active charcoal quality examination}

After the process of making activated charcoal with physical activation, the results of examination the water content and ash content of each sample are shown in Table 2.

Table 2. Data on the results of examination of hazelnut shell charcoal and activated charcoal from rice husk.

\begin{tabular}{lcc}
\hline \multicolumn{1}{c}{ Sample } & $\begin{array}{c}\text { Water } \\
\text { content }(\%)\end{array}$ & $\begin{array}{c}\text { Ash content } \\
(\%)\end{array}$ \\
\hline $\begin{array}{l}\text { Activated charcoal from } \\
\text { hazelnut shell }\end{array}$ & 3,398 & 6,667 \\
\hline $\begin{array}{l}\text { Activated charcoal from rice } \\
\text { husk }\end{array}$ & 3,355 & 8,667 \\
\hline
\end{tabular}

Table 2. shows that the water content and ash content of both activated charcoal samples meet the SNI requirements so that they can be used. Low water content and high ash content are influenced by the carbonization process with a temperature of $400^{\circ} \mathrm{C}$ and followed by a physical activation process with a temperature of $350^{\circ} \mathrm{C}$. The physical activation process leaves impurities in charcoal which can inhibit the evaporation process, it can also increase the amount of ash in the sample.

The water content in both activated charcoal is influenced by differences in the texture (softness) of the two samples. When there is a process of evaporation of water at a temperature of $100^{\circ} \mathrm{C}$, the rest of the water which is yield of the activated physically in the activated charcoal shell is trapped by a hard pore wall. On the contrary, the remaining water from physical activation in the activated charcoal of rice husk easily evaporates due to the softness of the pore wall. This is what causes the difference in water content in the two active charcoal, namely the water content in the activated charcoal shells higher than the water content in the activated charcoal of rice husk.

The ash content which is the mineral content of the material components contained in both activated charcoal was also influenced by differences in the texture (softness) of 
the two samples. When a carbonization and activation process occurs, leaving the organic components that are not completely burned in the two samples. So that this component will turn into ash when the sample is reheated. The high ash content found in activated charcoal from rice husks can reduce the absorption of activated charcoal both in solution and gas. The mineral content contained in ash such as potassium, calcium, sodium and magnesium will spread and stick to the activated pore charcoal.

From the data from the activated charcoal activation of the two samples, it can be said that the absorption capacity of candlenut shell charcoal is better than the absorption of activated charcoal from rice husk. For proof, it is applied to clarifying used cooking oil.

\section{Examination of activated charcoal shells and rice husks against used cooking oil}

\subsection{Peroxide Numbers}

The results of examination the used peroxide number of used cooking oil before and after purification using the activated charcoal shells and activated rice husk charcoal can be seen in Table 3.

Table 3. Data on the results of examination of used cooking oil peroxide

\begin{tabular}{ccc}
\hline No & $\begin{array}{c}\text { Sample } \\
\text { Code }\end{array}$ & $\begin{array}{c}\text { Peroxide } \\
\text { Numbers (meq) }\end{array}$ \\
\hline 1 & S0 & 2,73 \\
\hline 2 & S1 & 0,93 \\
\hline 3 & S2 & 1,13 \\
\hline
\end{tabular}

Table 3 shows that there is a decrease in peroxide number from the bleaching process on $\mathrm{S} 1$ by $66 \%$ and at $\mathrm{S} 2$ by $59 \%$ as seen in Figure 1. Or in other words the number of peroxide results from the bleaching process remaining at $\mathrm{S} 1$ is $34 \%$ and in S2 equal to $41 \%$, as seen in Figure 2.

\subsection{Free fatty acids}

Data from the results of testing of free fatty acids on used cooking oil before and after purification using activated charcoal shells and activated rice husk charcoal are presented in Table 4.

Table 4. Data on the results of testing of free fatty acids in used cooking oil

\begin{tabular}{ccc}
\hline No & $\begin{array}{c}\text { Sample } \\
\text { Code }\end{array}$ & $\begin{array}{c}\text { Free Fatty } \\
\text { Acid }(\%)\end{array}$ \\
\hline 1. & S0 & 0,33 \\
\hline 2. & S1 & 0,13 \\
\hline 3. & S2 & 0,18 \\
\hline
\end{tabular}

Table 4 shows that there was a decrease in the levels of free fatty acids resulting from the bleaching process on S1 by $60.6 \%$ and at S2 by $45.5 \%$ as seen in Figure 1. Or in other words the amount of free fatty acid results from the bleaching process left in $\mathrm{S} 1$ is $39.4 \%$ and in $\mathrm{S} 2$ is $54.5 \%$, as seen in Figure 2.

\subsection{Water content}

Data from the results of testing the moisture content of used cooking oil before and after purification using activated charcoal from pecan shells and activated charcoal from rice husk are presented in Table 5. 
Table 5. Data on the results of water content testing on used cooking oil

\begin{tabular}{ccc}
\hline No & Sample Code & Water Content $(\%)$ \\
\hline 1. & S0 & 0,46 \\
\hline 2. & S1 & 0,10 \\
\hline 3. & S2 & 0,27 \\
\hline
\end{tabular}

Table 5 shows that there was a decrease in water content from the bleaching process at $\mathrm{S} 1$ of $78.3 \%$ and in $\mathrm{S} 2$ of $41.3 \%$ as seen in Figure 1. Or in

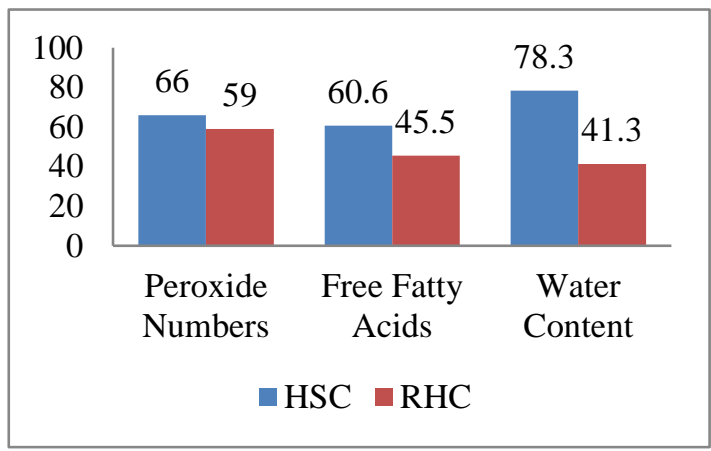

Figure 1. Decreasing concentration

Figure 1 and Figure 2 describe that activated charcoal ash is very significant for the purification process. This is because candlenut activated charcoal has a large surface area and pores, so it can bind and absorb free fatty acid compounds, reduce the amount of peroxide and the amount of water from used samples of used cooking oil.

\section{CONCLUSIONS}

Candlenut activated charcoal and active rice husk charcoal meet the requirements of SNI 06-3730-1995. However, the absorption capacity of candlenut shell charcoal is better than the absorption capacity of activated charcoal of rice husk.

The concentration of peroxide numbers, free fatty acid levels and moisture content of used cooking oil other words the amount of water content from the bleaching process remaining at $\mathrm{S} 1$ was $21,7 \%$ and at $\mathrm{S} 2$ of $58.7 \%$ as seen in Figure 2.

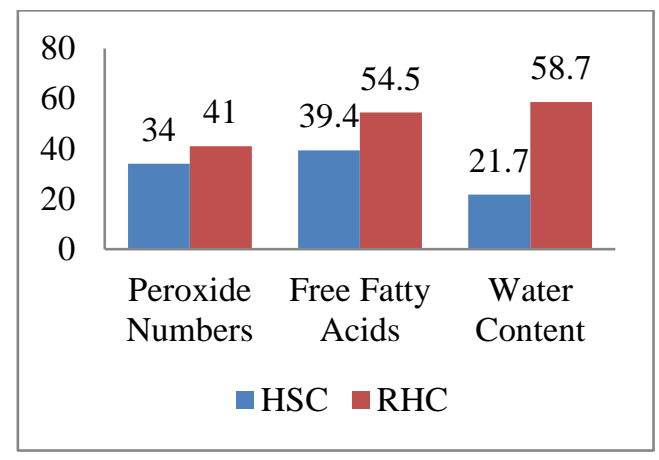

Figure 2. Concentration remaining

absorbed by the activated charcoal from the shells is higher than the activated charcoal of rice husk.

\section{REFERENCES}

Al-Qodah Z., dan Shawabkah R., 2009, Production And Characterization Ofgranular Activated Carbon From Activated Sludge, Brazilian Journal of Chemical Engineering, Vol. 26, No. 01, pp. $127-136$.

Aznar Sanchez Javier, 2011, Characterization of activated carbon produced from coffee residues by chemical and physical activation, Master Thesis in Chemical Engineering, Stockholm, Sweden.

Botahala Loth, Padalowa Nahor, Kaben Maksimus, 2016, Variation of contact time of the candlenut shell charcoal purification process used 
cooking oil, Indonesia Chimica Acta, Vol. 9, No. 2, (15 - 19)

Botahala L., Zakir M., Taba P., 2013, Role of Rice Husk Ash on the Physical Mechanical of Portland Composite Cement Quality by Use of Limestone Additives, Indonesia Chimica Acta, Vol. 6, No. 2, : 44-50.

Darmawan Saptadi, Pari Gustan, Sofian Kurnia, 2009, Temperature Optimization and long time of Activation with Phosphoric Acid in the Production of Pecan Shelled Active Charcoal, Jurnal Ilmu dan Teknologi Hasil Hutan, 2 (2): 51-56

Evika, 2011, The Use of Coconut Shell Active Charcoal Adsorbents in Purifying Used Cooking Oil, Thesis, Chemical Education Study Program, Tarbiyah and Teacher Training State Islamic University Sultan Syarif Kasim, Riau, Pekanbaru.

Indra Ade, Nurzal, Nofrianto Hendri, 2013, Effect of Combustion Temperature on Clay / Silica RHA Composites on Physical Properties (Application in Red Brick), Jurnal Teknik Mesin, Vol. 3, No. 2, : 60-65. Lempang Mody, Syafii Wasrin, Pari Gustan, 2012, Characteristics and Quality of Shellur Activated Charcoal, Jurnal Peneitian Hasil Hutan, Vol. 30, No. 2, Page. 100113.

Nasir, Neil S.W, Nurhaeni, dan Musafira. 2014. Utilization of Activated Charcoal from Kepok Banana (Musa normalis) as an Absorbent to Reduce Used Cooking Oil-Free Peroxide and Fatty Acid Figures, Journal Of Natural Science Vol. 3(1): 24-25.

Nur R., 2012, Purification of Used Cooking Oil Using Active Charcoal from Coconut Fiber, Thesis, Chemistry Study Program, Faculty of Mathematics and Natural
Sciences, Papua State University, Manokwari.

Padalowa Nahor, 2015, Effect of Time Variation of Candlenut Shell Activated Carbon Contact on Process of Used Cooking Oil Purification in Kalabahi Tengah Alor Village - NTT Regency, Thesis, Chemistry Study Program, Faculty of Mathematics and Natural Sciences, Tribuana Kalabahi University.

Santi, 2012. Study of Kinetics and Thermodynamics of Adsorption of Metal Ions $\mathrm{Pb}$ (II) and $\mathrm{Cu}$ (II) on Activated Carbon in Rice Husks Irradiated by Ultrasonic Waves. Thesis. Faculty of Mathematics and Natural Sciences, Hasanuddin University, Makassar.

Sudrajat P dan Tjipto Utomo. 2005. Production of Activated Carbon. Bandung Institute of Sciences. Bandung.

Surest, H. Azhary.J. A., Kasih Fitri, Wisanti Arfenny, 2008, The Effect of Temperature, Activator Concentration and Time of Activator on Absorption of Active Carbon from Candlenut Shell, Jurnal Teknik Kimia, Vol. 15, No. 2, : 17-21.

Taba Paulina, Arafah Mery, Budi Prastawa, Kasim Abd. Hayat, Fauziah St, Zakir M., 2013, Adsorption of Blue Methylene Color on Activated Carbon from Rice Husk by Utilizing Ultrasonic Wave Energy, Indonesia Chimica Acta, Vol. 6, No. 2, Hal. 27-36.

Wijayanti Kartika, 2015, Purity Level of Used Cooking Oil and Free Fatty Acid Levels with the Provision of Roselle Flowers and Cap Elephant Active Charcoal, Thesis, Biology Education Study Program, Teacher Training and Education Faculty, 
Surakarta Muhammadiyah University.

Zakir, M., Botahala, L., Ramang, M., Fauziah, S., \& Abdussamad, B. (2013). Electrodeposition of Mn Metals on Active Carbon Surfaces of Rice Husk by Ultrasonic Irradiation. Indo. Chim. Acta, 6(2). : 9-18. 